IJJM

Ilomata International Journal of Management

P-ISSN: 2714-8971; E-ISSN: 2714-8963

Vol. 1 No. 3 July 2020 pp. 83-87

https://www.ilomata.org/index.php/ijim

\title{
Debt to Equity Ratio (DER), Earning Per Share (EPS) Analysis of Company Value at PT Indosat, Tbk
}

\author{
Desi Ratnasari ${ }^{1}$, Puji Muniarty ${ }^{2}$ \\ ${ }^{12}$ Management Studies Program, Bima School of Economics, Bima City \\ Correspondent: puji.stiebima@gmail.com
}

Submitted : February 10, 2020 Revised : March 30, 2020 Published : July 30, 2020

\begin{abstract}
This study aims to analyze the effect of independent variables on the dependent variable. The independent variables are Debt to Equity Ratio (DER) and Earning Per Share (EPS) while the dependent variable is the Company Value at PT Indosat, Tbk for the period 2004-2018. The sample in this study over the past 15 years, namely from the period 2004-2018. The data used in this study is to use the company's financial statement data published on the Indonesia Stock Exchange (IDX) website and the company's official website. The data used are secondary data and the method used is regression analysis that is Time series data with the help of SPSS version 20.0 to get a picture of the relationship between one variable and another. The results showed that DER has no effect and no significant effect on firm value, EPS has no effect and no significant effect on firm value, DER and EPS simultaneously have no effect and no significant effect on firm value. The influence of DER and EPS on Company Value is 36.4\% while the remaining $63.6 \%$ is influenced by other factors not included in the research model.
\end{abstract}

Keywords: BEI, DER, EPS, COMPANY VALUE, Data Time Series

\section{INTRODUCTION}

The Indonesian economy in recent years has shown a fairly good development, it can be seen by the increasing number of companies that register themselves and sell their shares on the Indonesia Stock Exchange (IDX). One of these good developments is seen in telecommunications sector companies. Like other developing countries, the development of telecommunications infrastructure is an important factor in general economic development in Indonesia.

The telecommunications company is one of the most dynamic companies. Along with the times, various kinds of telecommunications services products began to emerge where many companies competed for optimal performance. The company manages production inputs into outputs that can meet community needs. Telecommunications have an important role because people need accurate, precise and fast information. As a business area, the telecommunications sector is also in great demand by business people, so that competition becomes very tight, companies must be able to make their respective strategies to be able to survive in existing competition. Technology facilitates human activities in communicating and exchanging information, using telecommunications which currently has many developments that are certainly able to save usage costs for consumers, but besides that, the company is required to compete with other companies while taking into account the risk of each decision taken.

Quoted from bisnis.com (Tuesday, April 10, 2014), the number of telecommunications operators in Indonesia is among the highest in the world, reaching 10 telecommunications companies. But of that number, there are six largest operators, namely Telkom. Telkomsel, 
Indosat, XL Axiata, Bakrie Telkom, and Smartfren. According to data from the Director-General of Post and Telecommunication, in the period 2006-2010, the average growth per year of cellular users in Indonesia reached $31.9 \%$ per year. Until the end of 2010, the number of cellular subscribers reached 211 million, with GSM operators dominating $95 \%$ of the cellular market, the remainder being the CDMA market of 5\%, while the cellular payment scheme was dominated by pre-paid $94 \%$ and the remaining post-paid (6\%).

In the era of globalization, the company was led to have a competitive advantage which was used to compete and compete with other companies by controlling market share. The rapid development of the cellular business is attracting investors to invest their funds in companies that are considered to provide benefits to investors and shareholders. Through operational activities, the company tries to get as much profit as possible. Business profits are not only important for the company itself but also an important element in creating corporate value that shows the company's prospects in the future and is a magnet for attracting investors by seeing the high value of the company.

The value of the company illustrates the company's ability to manage its resources, this can be seen from the company's financial statements in each period, the financial condition that is expected to attract investors' interest in the company. "Increasing company value is usually marked by rising share prices in the market" (Rahayu, 2010). Husnan \& Pudjiastuti (2012) the value of the company or also referred to as the company's market value is the price a prospective buyer is willing to pay if the company is sold. Price to book value (PBV) is one of the ratios used to measure company value. PBV shows the company's ability to create corporate value in the form of high share prices by utilizing available capital. The higher PBV means that the company can utilize the available capital to get maximum profit so that the company's shares have a high value because they have high interest.

Earnings per share is one of the things that is interesting for investors to make investment decisions for the company. If the profits generated by each share outstanding so well, the welfare of shareholders can be guaranteed by looking at the distribution of dividends at the end of each year. Earnings per share is part of the company's profit which is allocated for each share outstanding from ordinary shares. Hanafi and Halim (2015: 185) Earning per share or earnings per share is another financial ratio that is often used by stock investors (prospective stock investors) to analyze the ability of companies to make profits based on shares owned.

The debt to equity ratio describes the extent to which a company covers its debts with owned equity. "An increase in debt to a company will affect the size of the net income available to shareholders including dividends received because the obligation to pay debts takes precedence over dividend distribution" (Marlina \& Danica, 2009). The debt to equity ratio is one of the financial ratios classified as a solvency ratio group or often also called the leverage ratio. Debt to equity ratio (DER) according to Sitanggang (2014: 23), which is the ratio between total debt to total equity, in companies that provide a comparison between total debt and equity (equity). According to Kasmir (2014: 157-158), this ratio is useful to know the number of funds provided by the borrower (creditors) with the owner of the company. In other words, this ratio serves to find out every rupiah of its capital used as collateral for the debt. The debt to equity ratio standard, which is a financially sound company, is indicated by a DER ratio below 1 or below $100 \%$. Debt to equity ratio (DER) with a number below 1 identifies that the company has a debt that is smaller than its capital (equity). The results of previous studies conducted by (Pioh, Parengkuan, \& Srpang, 2018) showed that simultaneously the variables Debt to Equity Ratio, Earning Per Share and 
Debt to Equity Ratio (DER), Earning Per Share (EPS) Analysis of Company Value at PT Indosat, Tbk Ratnasari \& Muniarty

Return on Assets had a positive and significant effect on Company Value. Partially the Debt to Equity Ratio variable has a significant effect on Company Value (Pioh, Tommy, \& Parengkuan, 2018), Debt to Equity Ratio has no significant effect on Company Value (Lebelaha \& Saerang, 2016 ). Earnings Per Share partially does not affect the Company Value of research (Wicaksana, Djailani \& Anwarodin), Earning Per Share partially affects Company Value (Sandrawati, 2016).

\section{METHOD}

In this study using associative research with a quantitative approach. Quantitative research is research that concentrates on testing theories through variables in the form of numbers and then analyzing data by statistical processes both manual and computer software. The population in this study is the balance sheet financial statement data consisting of data on current debt, long-term debt, total equity, number of shares outstanding, share price and profit and loss from net income for 25 years, from 1994 to 2018. The sample in this study is the balance sheet financial statement data consisting of data on current debt, long-term debt, total equity, number of shares outstanding, share price and profit and loss on net income over the past 15 years, from 2004 to 2018 by sampling purpose sampling. The reason for using purpose sampling is the availability of data that is easily accessible and up to date, the data needed in the study are already listed in the financial report of PT Indosat, Tbk and representative data representation following the indicator variables studied. Data analysis in this study used multiple linear regression analysis, multiple correlation coefficients, multiple coefficients of determination (R2), t-test, and F test, namely time series data. Time series data are the values of a variable sequentially according to time for example days, weeks, months and years. In this study using the SPPS program version 20.0.

The framework of thinking in this study is as follows:

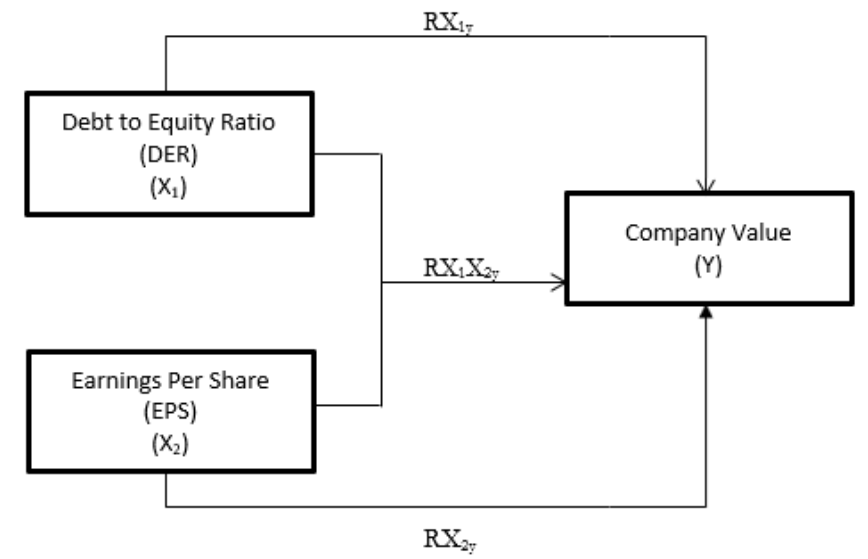

\section{RESULT AND DISCUSSION}

Table 1. Multiple linear regression analysis

\begin{tabular}{|c|c|c|c|c|c|c|c|c|c|c|c|}
\hline \multicolumn{12}{|c|}{ Coefficients $^{a}$} \\
\hline & \multirow[t]{2}{*}{ Model } & \multicolumn{2}{|c|}{$\begin{array}{l}\text { Unstandardized } \\
\text { Coefficients }\end{array}$} & \multirow{2}{*}{\begin{tabular}{|c|}
$\begin{array}{c}\text { Standardized } \\
\text { Coefficients }\end{array}$ \\
Beta \\
\end{tabular}} & \multirow[t]{2}{*}{$\mathrm{T}$} & \multirow[t]{2}{*}{ Sig. } & \multicolumn{3}{|c|}{ Correlations } & \multicolumn{2}{|c|}{$\begin{array}{l}\text { Collinearity } \\
\text { Statistics }\end{array}$} \\
\hline & & $\mathrm{B}$ & Std. Error & & & & Zero-order & Partial & Part & Tolerance & VIF \\
\hline \multirow{3}{*}{1} & (Constant) & 194.405 & 58.027 & & 3.350 & .006 & & & & & \\
\hline & DER & -.073 & .253 & -.094 & -.290 & .777 & -.469 & -.083 & -.067 & .506 & 1.976 \\
\hline & EPS & 9.654 & 5.848 & .534 & 1.651 & .125 & .600 & .430 & .380 & .506 & 1.976 \\
\hline
\end{tabular}

Source: SPSS version 20.0 output 
Debt to Equity Ratio (DER), Earning Per Share (EPS) Analysis of Company Value at PT Indosat, Tbk Ratnasari \& Muniarty

Based on the table above can be obtained equation of multiple linear regression equations, namely: $\mathrm{Y}=194,405-0,073+9,654$.

\section{Table 2. Multiple correlation coefficient}

Model Summary ${ }^{b}$

\begin{tabular}{|l|r|r|r|r|r|r|r|r|r|r|}
\hline Model & \multirow{2}{*}{$\mathrm{R}$} & $\mathrm{R}$ Square & \multirow{2}{*}{$\begin{array}{c}\text { Adjusted R } \\
\text { Square }\end{array}$} & $\begin{array}{c}\text { Std. Error of } \\
\text { the Estimate }\end{array}$ & $\begin{array}{c}\text { R Square } \\
\text { Change }\end{array}$ & F Change & df1 & df2 & $\begin{array}{c}\text { Sig. F } \\
\text { Change }\end{array}$ & $\begin{array}{l}\text { Durbin- } \\
\text { Watson }\end{array}$ \\
\hline 1 & $.604^{2}$ & .364 & .259 & 45.468161 & .364 & 3.441 & 2 & 12 & .066 & 1.090 \\
\hline
\end{tabular}

Source: SPSS version 20.0 output

The value of multiple correlations is 0.604 which means that the level of closeness of the relationship between the DER and EPS variables to the value of the company is at a strong level.

Based on the processed SPSS Version 20.0, the Determination Coefficient $\left(\mathrm{R}^{2}\right)$ value of 0.364 means that the effect of Debt to Equity Ratio (DER), Earning Per Share (EPS) Analysis of Company Value at PT Indosat, Tbk is 36,40 while the remaining $63.60 \%$ is influenced by other factors not examined in this study.

Based on table 1, the values for each DER $\left(\mathrm{X}_{1}\right)$ obtained t-statistics of $-0.290<\mathrm{t}$-table 2.179 , and sig value of $0.777>0.05$, it can be concluded that the DER variable partially has no effect and is not significant on firm value. EPS $\left(\mathrm{X}_{2}\right)$ obtained a t-value of $1.651<\mathrm{t}$-table of 2.179 , and the sig value of $0.125>0.05$, it can be concluded that the EPS variable partially has no significant effect on firm value.

Table 5. F-test

ANOVA $^{a}$

\begin{tabular}{|ll|l|l|l|l|l|}
\hline Model & & Sum of Squares & Df & Mean Square & F & Sig. \\
\hline \multirow{4}{*}{1} & Regression & 14227.433 & 2 & 7113.717 & 3.441 & $.066^{\mathrm{b}}$ \\
& Residual & 24808.244 & 12 & 2067.354 & & \\
& Total & 39035.678 & 14 & & & \\
\hline
\end{tabular}

a. Dependent Variable: COMPANY VALUE

b. Predictors: (Constant), EPS, DER

Source: SPSS version 20.0 output

Based on the simultaneous test (F-Test) the value of F table is 3.441, and the F-count value can be $3.88(3,441<3.88)$ and a significant value of $0.066>0.05$. Then it can be concluded that there is not the simultaneous influence between DER, EPS variables on firm value.

\section{CONCLUSION}

Based on the t-test, the values for each DER $\left(\mathrm{X}_{1}\right)$ obtained t-statistics of $-0.290<\mathrm{t}$-table 2.179 , and sig value of $0.777>0.05$, it can be concluded that the DER variable partially has no effect and is not significant on firm value. EPS $\left(\mathrm{X}_{2}\right)$ obtained a $\mathrm{t}$-value of $1.651<\mathrm{t}$-table of 2.179 , and the sig value of $0.125>0.05$, it can be concluded that the EPS variable partially has no significant effect on firm value.

Based on the simultaneous test (F-Test) the value of F table is 3.441, and the F-count value can be $3.88(3,441<3.88)$ and a significant value of $0.066>0.05$. Then it can be concluded that there is not the simultaneous influence between DER, EPS variables on firm value.

For other researchers, it is hoped that the results of this study can be used as a reference to study other variables besides the problem of debt to equity ratio (DER), earning per share (EPS), and company value which have been discussed by various authors and indicators and supported by the latest theories or research. For the number of observations, it must be added, both in terms of cross-section and time series. 
Debt to Equity Ratio (DER), Earning Per Share (EPS) Analysis of Company Value at PT Indosat, Tbk Ratnasari \& Muniarty

\section{REFERENCE}

Alif Wahyu Wicaksana, Abdul Qodir Djailani \& M. Khoirul Anwarodin BS, (2018). Analisis Pengaruh Return On Assets (ROA), Earning Per Share (EPS), dan Debt to Equity Ratio (DER) terhadap Nilai Perusahaan. e-Jurnal Riset ManajemenPRODI MANAJEMEN. 7(1): 90-101.

Devina L. A. Lebelaha \& Ivonne S. Saerang, (2016). Pengaruh Price Earnings Ratio, Debt to Equity Ratio dan Dividend Payout Ratio terhadap Nilai Perusahaan BUMN yang Terdaftar di Bursa Efek Indonesia periode 2011-2014. Jurnal Berkala Ilmiah Efisiensi. 16(2): 376-386.

Hanafi \& Halim, (2017). Pengaruh Debt to Equity Ratio Dan Earning Per Share terhadap Harga Saham Pada Perusahaan Farmasi Yang Terdaftar di Bursa Efek Indonesia (BEI). Jurnal Studia Akuntansi dan Bisnis. 5(2): 79-90.

Hizkia T.Pioh, Parengkuan Tommy \& Jantje L. Srpang, (2018). Pengaruh Debt to Equity Ratio, Earning Per Share dan Return On Asset terhadap Nilai Perusahaan Sub Sector Food and Beverages di Bursa Efek Indonesia. Jurnal EMBA. 6(4): 3018-3027.

Husnan \& Pudjiastuti. (2018). Analisis Pengaruh Return On Assets (ROA), Earning Per Share (EPS), dan Debt to Equity Ratio (DER) terhadap Nilai Perusahaan. e-Jurnal Riset ManajemenPRODI MANAJEMEN 7(1): 90-101.

Marlina \& Danica, (2018). Analisis Pengaruh Return On Assets (ROA), Earning Per Share (EPS), dan Debt to Equity Ratio (DER) terhadap Nilai Perusahaan. e-jumal Riset ManajemenPRODI MANAJEMEN 7(1): 90-101.

Sitanggang, (2018). Pengaruh Debt to Equity Ratio, Return On Equity, Return On Asset, dan Ukuran Perusahaan terhadap Perusahaan. Jurnal Administrasi Bisnis(JAB). 57(1): 151-159.

Rahayu, (2018). Analisis Pengaruh Return On Assets (ROA), Earning Per Share (EPS), dan Debt to Equity Ratio (DER) terhadap Nilai Perusahaan. e-Jurnal Riset ManajemenPRODI MANAJEMEN. 7(1): 90-101.

Sandrawati, Vera (2016). Pengaruh Debt to Equity Ratio, Return On Asset, Earning Per Share dan Risiko Sistematis terhadap Nilai Perusahaan (Studi Pada Perusahaan Kategori LQ45 Yang Terdaftar di BEI 2011-2014). Jumal Akuntansi Universitas Maritim Raja Ali Haji.

Sofyan, M. (2019). Analysis Financial Performance of Rural Banks in Indonesia. International Journal of Economics, Business and Accounting Research (IJEBAR), 3(3), pp. 255-262. 